\title{
PROBLEMATIK HAK CIPTA ATAS CIPTAAN BERDASARKAN PESANAN ATAU HUBUNGAN KERJA (STUDI PADA PRODUK BATIK KOTA SEMARANG)
}

\author{
Dewi Sulistianingsih, Rini Fidiyani, Pujiono, Hesty Alya Utami \\ Fakultas Hukum Universitas Negeri Semarang \\ Gedung K Kampus Sekaran Gunungpati Semarang, \\ Jawa Tengah, Indonesia 50229 \\ Email: dewisulistianingsih21@gmail.com
}

\begin{abstract}
Abstrak
Ciptaan yang dibuat atau diciptakan oleh pencipta merupakan hasil karya kreativitasnya yang terjadi karena intelektual dari si pencipta. Hak cipta umumnya dimiliki oleh orang yang membuat ciptaan tersebut, namun ada beberapa pengecualian yaitu diantaranya ciptaan yang dibuat berdasarkan pesanan atau hubungan kerja. Pada umumnya pemberi kerja akan memiliki hak kekayaan intelektual yang dibuat oleh karyawannya selama masa kerja mereka. Karyawan yang menciptakan karya tanpa ada hubungannya dengan perusahaan dimana dia bekerja, maka kepemilikan hak cipta atas ciptaan tersebut ada pada si karyawaan. Konflik akan muncul jika lahirnya suatu ciptaan tanpa ada ketentuan yang jelas mengenai siapa pencipta dari karya tersebut.

Tulisan ini bertujuan untuk mengungkapkan problematik kepemilikan hak cipta dimana ciptaan dibuat atas dasar pesanan atau hubungan kerja. Tulisan ini berdasarkan Penelitian yang dilakukan dengan metode pendekatan yuridis empiris. Spesifikasi yang dipergunakan dalam penelitian ini adalah deskriptif analitis. Lokasi penelitian ini adalah di Kota Semarang. Data penelitian dikumpul dengan cara wawancara, dokumentasi dan observasi langsung di lapangan.

Pelaku usaha produk Batik di Kota Semarang selain memperjualkan produk batik buatan sendiri juga menjual produk berdasarkan pesanan dari sebuah perusahaan atau isntansi. Pesanan ini tidak hanya berupa kain tetapi dapat pula sampai berupa kain yang sudah dijahitkan menjadi sebuah pakaian jadi. Motif yang digunakan dapat bervariasi, umumnya atas permintaan dari pihak pemesan itu sendiri. Kegiatan sederhana ini menjadi tantangan bagi pelaku usaha maupun pihak pemesan. Manakala terjadi konflik penentuan siapa pemegang hak cipta atas motif tersebut. Jika perjanjian yang dilakukan antara pelaku usaha dengan pihak pemesan sudah membicarakan hal tersebut, hal ini akan lebih mudah untuk menentukan siapa pemilik hak cipta tersebut, namun jika perjanjian tidak menjelaskan siapa pemegang hak ciptanya maka akan terbuka konflik kepemilikan hak cipta atas motif produk batik pesanan tersebut.
\end{abstract}

Kata kunci: pencipta, ciptaan, hubungan kerja 


\section{A. PENDAHULUAN}

Karya intelektual dilahirkan dengan pengorbanan tenaga, waktu dan biaya. Pengorbanan tersebut yang telah menjadikan karya yang dihasilkan memiliki nilai. Karya intelektual yang memiliki nilai tambah seperti nilai ekonomi maka karya intelektual tersebut dapat menjadi aset bagi perusahaan. Aset tersebut merupakan aset yang bersifat intangible namun memiliki nilai ekonomi yang sangat bermanfaat bagi kemajuan perusahaan. Karya intelektual yang bernilai tersebut dalam hukum dapat diberikan perlindungan dengan menggunakan mekanisme hak kekayaan intelektual. Hak kekayaan intelektual merupakan hak atas kepemilikan terhadap karya-karya yang timbul atau lahir dari kemampuan intelektual seseorang dalam bidang seni, ilmu pengetahuan, dan teknologi.

Kekayaan intelektual memiliki runag lingkup yang cukup luas diantaranya kekayaan intelektual yang sifatnya komunal dan kekayaan intelektual yang sifatnya pribadi (individual). Kekayaan intelektual yang sifatnya komunal seperti folklore, traditional knowledge, dll. Sedangkan kekayaan intelektual yang sifatnya pribadi (individual) yaitu cipta, paten, merek, desain industri, dll.

Salah satu lingkup HKI yang dilindungi adalah hak cipta. Di Indonesia, pengaturan tentang hak cipta mengalami beberapa kali perubahan dan pergantian undang-undang yaitu Undang-Undang Nomor 8 Tahun 1982 yang diperbaharui dengan Undang- Undang Nomor 17 Tahun 1987 dan diperbaharui lagi dengan Undang-Undang Nomor 12 Tahun 1997, Undang-Undang Nomor 19 Tahun 2002 dan yang terakhir yakni Undang-Undang Nomor 28 Tahun 2014 (selanjutnya disebut dengan UUHC). Berdasarkan ketentuan Pasal 1 ayat (1) Undang-Undang No. 28 Tahun 2014 tentang Hak Cipta yang dimaksud dengan Hak Cipta adalah Hak eksklusif bagi pencipta atau penerima hak untuk mengumumkan atau memperbanyak ciptaannya atau memberikan izin untuk itu dengan tidak mengurangi pembatasan-pembatasan menurut peraturan perundangan-undangan yang berlaku.

Pencipta atau pemegang hak cipta atas suatu ciptaan terdiri atas beberapa bagian yakni jika suatu ciptaan terdiri atas beberapa bagian yang diciptakan dua orang atau lebih, yang dianggap sebagai pencipta ialah orang yang memimpin 
serta mengawasi penyelesaian seluruh ciptaan itu, atau dalam hal tidak ada orang tersebut, yang dianggap sebagai pencipta ialah orang yang menghimpunnya dengan tidak mengurangi hak cipta masing-masing atas bagian ciptaannya itu. Sedangkan menurut Kristen B. Kennedy yakni ${ }^{26}$ A basic tenet of American law is that the creator of an original work has exclusive rights to any profits or proceeds derived from that work for a certain length of time.

Penentuan siapa pencipta dan pemegang hak cipta akan menjadi persoalan rumit jika dihadapkan pada permasalahan ciptaan yang dibuat berdasarkan pesanan atau di bawah kontrak (perjanjian) antara pelaku usaha (pengusaha) dengan karyawannya (pekerjanya). Cara menentukan siapa pencipta dari ciptaan yang dihasilkan berdasarkan pesanan dan berdasarkan kontrak kerja antara pelaku usaha dengan para pekerjanya, harus berhati-hati, mengingat hal ini berpotensi menimbulkan konflik di kemudian hari setelah ciptaan tersebut selesai (jadi).

Pelaku usaha sering mempekerjakan dan mungkin saja berinvestasi pada karyawan untuk mengembangkan produk baru, meningkatkan proses, menciptakan teknologi baru, dan mengembangkan pangsa pasar baru. Dengan investasi ini, seharusnya tidak mengherankan bahwa pelaku usaha pada umumnya memiliki kekayaan intelektual yang diciptakan oleh karyawannya selama masa kerja mereka. Namun, kekayaan intelektual yang diciptakan oleh seorang karyawan, selain dalam hal pekerjaan, dimiliki oleh karyawan bukan pemilik perusahaan. Prinsip-prinsip sederhana ini menghadirkan tantangan bagi karyawan dan pengusaha (pelaku usaha).

Pelaku usaha produk batik di Kota Semarang merupakan pelaku usaha yang cenderung kecil dan menengah ${ }^{27}$. Namun, ada juga pelaku usaha yang sudah memiliki beberapa karyawan yang dipekerjakannya. Beberapa pelaku usaha produk batik di Kota Semarang mendapatkan pesanan membuat produk batik,

${ }^{26}$ Kennedy, Kristen B. (2017). Copyright Infringement in Sound Recording: How Courts and Legislatures Can Get in Vogue in a Post-Ciccone World. Vol.25, Number 12. Halaman 20

${ }^{27}$ Umumnya pelaku usaha batik merupakan UMKM, seperti apa yang diungkapkan oleh Evi Steelyana bahwa Batik industry in Indonesia is part of the Small Medium Enterprise or SME. Lihat Evi Steelyana, 2012, Batik, A Beautiful Cultural Heritage That Preserve Culture And Support Economic Development In Indonesia, Binus Business Review, Vol. 3, No. 1, 116-130, halaman 128. 
dengan ketentuan yang bervariasi, motif dari si pemesan atau pemesan meminta motif dari si pelaku usaha. Selain itu pelaku usaha dalam membuat produk batik juga mendesain sendiri motifnya dengan dibantu oleh para pekerjanya. Ide bisa saja berasal dari si pelaku usaha itu senidri atau dari si pekerjanya. Penentuan siapa pencipta dari motif batik tersebut harus dilihat dengan berbagai unsur yaitu siapa yang memiliki ide, adakah perjanjian sebelumnya, dll. Hal ini akan menimbulkan sengketa di kemudian hari manakala hak cipta berada bukan pada si pencipta aslinya.

Sengketa tentang Hak Kekayaan Intelektual khususnya bidang hak cipta tidak terhindarkan. Biasanya sengketa pada masalah yang bersinggungan dengan pendaftaran hak cipta, yang terkait dengan siapa pencipta atau pemegang hak cipta dari ciptaan tersebut. Kasus yang terjadi mengenai siapa pencipta dan pemegang hak cipta apabila ciptaan tersebut berasal dari suatu hubungan kerja, yang dimana pihak yang pertama yakni perusahaan memerintahkan karyawan atau pekerja nya membuat suatu ciptaan guna keperluan suatu perusahaan tersebut.

Berdasarkan hal tersebut di atas, maka permasalahan yang timbul terkait dengan persoalan hak cipta pada ciptaan atas pesanan atau hubungan kerja yaitu: (1). Bagaimana perlindungan hukum suatu ciptaan yang dibuat berdasarkan pesanan atau hubungan kerja; (2) Siapakah pencipta/pemegang hak cipta dalam suatu hubungan kerja?

\section{B. METODE PENELITIAN}

Penelitian ini merupakan penelitian yang berjenis penelitian kualitatif. Pemilihan jenis penelitian kualitatif didasarkan pada pertimbangan bahwa data yang akan diperoleh sebagian besar berupa kata-kata, perkataan, ujaran dari para responden dan informan penelitian. Pendekatan penelitian ini adalah yuridis empiris dengan melihat dengan jelas realitas-realitas yang ada dalam masyarakat perkembangan produk batik lokal (Semarang). Penelitian ini mengambil lokasi di Kota Semarang. Pemilihan kota Semarang sebagai lokasi penelitian didasarkan pada pertimbangan bahwa kota Semarang memiliki pusat-pusat usaha batik lokal yang sedang berkembang dan memiliki ciri khas (pakem) dari Kota Semarang. 
Data dalam penelitian ini diperoleh melalui kegiatan-kegiatan observasi, interview $^{28}$, visual, interpelasi dokumen (teks) dan material, serta personal experience $^{29}$. Sesuai dengan paradigma penelitian ini, dalam melakukan observasi peneliti akan mengambil posisi sebagai participant observer. Peneliti adalah instrument utama (key instrument $)^{30}$ dalam pengumpulan data. Indepth interview dilakukan dengan pertanyaan-pertanyaan terbuka (open ended), namun tidak menutup kemungkinan akan dilakukan pertanyaan-pertanyaan tertutup (closed ended) terutama untuk informan yang memiliki banyak informasi tetapi ada kendala dalam mengelaborasi informasinya tersebut. Penelitian ini dilengkapi dengan library research tentang teori-teori yang mendukung analisis problematika yang diajukan, maupun hukum positif berupa peraturan perundang-undangan yang terkait dengan hak cipta. Pendapat para ahli di bidang ini juga akan dijadikan rujukan untuk mendukung data empirik yang diperoleh.

Terhadap data primer, digunakan teknik analisis data tipe Stratuss dan J Corbin $^{31}$, yaitu dengan menganalisis data sejak peneliti berada dilapangan. Oleh karena itu selama dalam penellitian, peneliti menggunakan analisis interaktif dengan menggunakan fieldnote yang terdiri atas deskripsi dan refleksi data ${ }^{32}$. Selanjutnya peneliti melakukan kalsifikasi data melalui proses indexing, sharing, grouping, dan filtering. Setelah data penelitian dianggap valid dan reliable, langkah selanjutnya adalah merekonstruksi dan menganalisisnya secara induktif kualitattif, untuk menjawab problematika yang menjadi fokus studi penelitian ${ }^{33}$. Langkah-langkah teknik analisis data penelitian ini mengikuti model interaktif analisis data seperti yang dikemukakan oleh Mettew B. Miles dan A. Michael

\footnotetext{
${ }^{28}$ Amanda Coffey, 2004, Reconceptualizing Social Policy: Sosiological Perspective on Contemporary Social policy, Berkshire-England: Open University Press, McGraw Hill Educations, halaman 120.

${ }^{29}$ Sanfiah, Faisal, 1990. Penelitian Kualitatif : Dasar-Dasar dan Aplikasinya, Malang : Yayasan Asah Asih Asuh, halaman 80.

${ }^{30}$ Nasution. 1992. Metode Penelitian Naturalistik. Bandung : Tarsito, halaman 9. Lihat pula Bogdan, Robert dan Steven J. Taylor. 1992. Pengantar Metode Penelitian Kualitatif.Terjemahan Ali Furchan, Surabaya : Usaha Nasional, halaman 31-32.

${ }^{31}$ Strauss, A and J. Corbin. 1990. Qualitative Research, Grounded Theory Procedure and Techniques, London: Sage Publication, halaman 19.

32 Sutopo, H.B, 1990, Metodologi Penelitian Kualitatif Bagian II, Surakarta: Universitas Sebelas Maret Press, halaman 11.

${ }^{33}$ Sudarto, 2002, Metode Penelitian Filsafat, Jakarta : Raja Grafindo, halaman 57.
} 
Huberman $^{34}$ yang bergerak dalam tiga siklus kegiatan, yaitu reduksi data, penyajian data dan penarikan simpulan atau verifikasi.

Terhadap data sekunder, dalam mencari kebenaran umum akan dilakukan dengan menggunakan logika deduktif, khususnya pada saat analisis awal (penggunaan teori-teori), namun tidak menutup kemungkinan dilakukan analisis dengan menggunakan logika induktif terhadap kasus-kasus sengketa antara pelaku usaha dengan konsumen yang telah terdokumentasi dalam bentuk hasil-hasil studi, pencatatan maupun hasil penelitian.

\section{HASIL PENELITIAN DAN PEMBAHASAN}

Pelaku usaha produk batik di Kota Semarang merupakan pengusaha kecil (dapat dikatakan masih dalam lingkup UMKM). Pelaku usaha ini dijalankan dengan sistem kekeluargaan namun ada juga dengan sistem yang lebih modern yaitu memiliki para pekerja yang bekerja untuknya. Tidak banyak pelaku usaha produk batik di Kota Semarang, jika dibandingkan dengan kota seperti Pekalongan, Lasem, Solo, dll. Namun dapat dianalisis bahwa eksistensinya masih tetap ada dan tetap berkembang di Kota Semarang. Di Kota Semarang terdapat 41 pelaku usaha batik yang sampai saat ini masih eksis dan jumlah ini masih terus bertambah.

Tabel 1: Data Pelaku Usaha Produk Batik Kota Semarang

\begin{tabular}{|c|l|l|l|}
\hline No & \multicolumn{1}{|c|}{ Nama Produk } & \multicolumn{1}{|c|}{ Pemilik } & \multicolumn{1}{|c|}{ Kecamatan } \\
\hline 1 & BATIK EL DINA & Yul Sumardi & $\begin{array}{l}\text { Semarang } \\
\text { Selatan }\end{array}$ \\
\hline 2 & SITI MUNJIAMAH & Siti Munjiamah & $\begin{array}{l}\text { Semarang } \\
\text { Selatan }\end{array}$ \\
\hline 3 & RATRI & $\begin{array}{l}\text { Ratri Septina Saraswati } \\
\text {,ST,MT }\end{array}$ & $\begin{array}{l}\text { Semarang } \\
\text { Selatan }\end{array}$ \\
\hline 4 & BOKOR KENCONO & Dewi Tunjung & $\begin{array}{l}\text { Semarang } \\
\text { Selatan }\end{array}$ \\
\hline 5 & MARTHA & Martha & $\begin{array}{l}\text { Semarang } \\
\text { Selatan }\end{array}$ \\
\hline
\end{tabular}

34 Miles, Matthew B dan A. Michael Huberman. 1992. Analisis Data Kualitatif. Terjemahan Tjetjep Rohendy Rohidi. Jakarta : UI Press, halaman 22. 


\begin{tabular}{|c|c|c|c|}
\hline 6 & BATIK PASHA & Ny. Pasha & Semarang Timur \\
\hline 7 & ELLY BATIK & Elizabeth Algonda & Semarang Timur \\
\hline 8 & $\begin{array}{l}\text { BATIK } \\
\text { SEMARANG } \\
\text { INDAH }\end{array}$ & $\begin{array}{l}\text { Iin Windhi Indah } \\
\text { Tjahjani }\end{array}$ & Semarang Timur \\
\hline 9 & KEBOEN BATIK & Erwin / Bu Jannah & Semarang Timur \\
\hline 10 & AMBAR YANI & Ambar Yani & Semarang Timur \\
\hline 11 & LILIK LATIFAH & Lilik Latifah & Semarang Timur \\
\hline 12 & RUMIYATI & Rumiyati & Semarang Timur \\
\hline 13 & $\begin{array}{l}\text { BATIK ASEM } \\
\text { ARANG }\end{array}$ & Endang Purwanti & Semarang Timur \\
\hline 14 & ANISA AYUTIA V & Anisa Ayutia v & Semarang Timur \\
\hline 15 & $\begin{array}{l}\text { YUSTINA PUJI } \\
\text { LESTARI }\end{array}$ & Yustina Puji Lestari & Semarang Timur \\
\hline 16 & $\begin{array}{l}\text { ARIE SUWITO } \\
\text { WIBOWO }\end{array}$ & Arie Suwito Wibowo & Semarang Timur \\
\hline 17 & $\begin{array}{l}\text { UTOMO AGUNG } \\
\text { NUGROHO }\end{array}$ & Utomo Agung Nugroho & Semarang Timur \\
\hline 18 & DWI ARISTONO & Dwi Aristono & Semarang Timur \\
\hline 19 & ZIE BATIK & Marheno & Semarang Timur \\
\hline 20 & GALIH SURYO . P & Galih Suryo P & Semarang Timur \\
\hline 21 & NAJMY BATIK & Susi Winarti & Semarang Timur \\
\hline 22 & SUTJI & $\begin{array}{l}\text { Sutji Julianti / Choirul } \\
\text { Anwar }\end{array}$ & Semarang Barat \\
\hline 23 & $\begin{array}{l}\text { WIJAYANTI } \\
\text { BATIK }\end{array}$ & Wiwik & Semarang Barat \\
\hline 24 & IDA & Ida Noviani Gafur & Banyumanik \\
\hline 25 & SITI & Siti Kholifah & Banyumanik \\
\hline 26 & ATIEK & Atiek Setiyati & Gajahmungkur \\
\hline 27 & NUGROHO PANJI & Nugroho Panji & Gajahmungkur \\
\hline 28 & R. HERU S, SE. & R. Heru S. SE. & Tembalang \\
\hline 29 & $\begin{array}{l}\text { BATIK } \\
\text { SEMARANG } 16\end{array}$ & $\begin{array}{l}\text { Umi Sumiyati / Ir. } \\
\text { Slamet }\end{array}$ & Tembalang \\
\hline 30 & NGATMI & Ngatmi & Tembalang \\
\hline 31 & SUYATMI & Suyatmi & Gajahmungkur \\
\hline 32 & SRI & Sri Suyastin & Mijen \\
\hline
\end{tabular}




\begin{tabular}{|c|l|l|l|}
\hline 33 & UNIK & Unik Wahyuningsih & Mijen \\
\hline 34 & ARIANI & Ariani Purnawati & Mijen \\
\hline 35 & UMI SALAMAH & Umi Salamah & Gunungpati \\
\hline 36 & ISMUN & Ismun & Gunungpati \\
\hline 37 & MARHINO & Marhino & Gunungpati \\
\hline 38 & SUS & Suswahyuni, SA & Pedurungan \\
\hline 39 & $\begin{array}{l}\text { ENDANG } \\
\text { WAHYUNINGSIH }\end{array}$ & Endang Wahyuningsih & Pedurungan \\
\hline 40 & $\begin{array}{l}\text { DWI ATMI } \\
\text { RAHMAWATI }\end{array}$ & Dwi Atmi Rahmawati & Genuk \\
\hline 41 & MUSSODAKOH & Mussodakoh & Genuk \\
\hline
\end{tabular}

Sumber: Data penelitian yang telah di olah dari Disperindag Provinsi

Jawa Tengah tahun 2017

Pelaku usaha produk batik di Kota Semarang pada umumnya memiliki motif sendiri-senidiri sebagai ciri khas nya. Namun tak banyak pula yang membuat motif sendiri karena di dasarkan oleh pesanan. Pemesan ini umumnya adalah sebuat institusi pemerintah ataupun badan usaha swasta. Seperyi apa yang di ungkapkan oleh Nofi bahwa beberapa pemesan terkadang menyiapkan motif mereka sendiri dan minta untuk di buatkan kain batiknya ${ }^{35}$. Pesanan tersebut sudah dibuatkan perjanjian tertulis termasuk siapa pemilik motif tersebut. Pelaku usaha hanya diminta untuk membuatkan kain batik dengan motif dari si pemesan. Ada pula pemesan yang hanya meminta untuk di buatkan kain batik tetapi motif dari pelaku usaha. Hal ini umumnya tidak ada perjanjian tertulis, hanya perjanjian jual beli biasa.

\section{Perlindungan Hukum Suatu Ciptaan dibuat berdasarkan Pesanan atau}

\section{Hubungan Kerja}

Undang-Undang Nomor 28 Tahun 2014 tentang Hak Cipta dikatakan bahwa Hak Cipta adalah hak eksklusif pencipta yang timbul secara otomatis berdasarkan prinsip deklaratif setelah suatu ciptaan diwujudkan dalam bentuk nyata tanpa mengurangi pembatasan sesuai dengan ketentuan peraturan perundang-undangan.

\footnotetext{
${ }^{35}$ Wawancara dengan Nofi, Pemilik Razaqa Batik, wawancara tanggal 30 Juli 2018.
} 
Pencipta adalah seorang atau beberapa orang yang secara sendiri-sendiri atau bersama-sama menghasilkan suatu ciptaan yang bersifat khas dan pribadi, ciptaan adalah setiap hasil karya cipta di bidang ilmu pengetahuan, seni, dan sastra yang dihasilkan atas inspirasi, kemampuan, pikiran, imajinasi, kecekatan, keterampilan, atau keahlian yang diekspresikan dalam bentuk nyata.

Berdasarkan ketentuan Pasal 1 ayat (4) Undang-Undang No. 28 Tahun 2014 tentang Hak Cipta yang dimaksud dengan Pemegang Hak Cipta adalah Pencipta sebagai pemilik Hak Cipta, pihak yang menerima hak tersebut secara sah dari Pencipta, atau pihak lain yang menerima lebih lanjut hak dari pihak yang menerima hak tersebut secara sah.

Untuk perlindungan terhadap suatu ciptaan timbul secara otomatis sejak ciptaan itu diwujudkan dalam bentuk nyata. Pendaftaran ciptaan tidak merupakan suatu kewajiban untuk mendapatkan hak cipta. Namun demikian, pencipta maupun pemegang hak cipta yang mendaftarkan ciptaannya akan mendapat surat pendaftaran ciptaan yang dapat dijadikan sebagai alat bukti awal di pengadilan apabila timbul sengketa di kemudian hari terhadap penciptaan tersebut.

Berbeda dengan merek dagang, di Indonesia tidak ada ketentuan yang mewajibkan pendaftaran ciptaan untuk mendapatkan hak cipta.Pendaftaran ciptaan dalam daftar umum ciptaan tidak mengandung arti sebagai pengesahan atas isi, arti, maksud, atau bentuk dari ciptaan yang didaftar. Hal ini dikarenakan, hak cipta telah lahir begitu ciptaan selesai dibuat. Dasar pemberian hak cipta bukan terletak pada pendaftarannya, tetapi pada ekspresi ide bentuknya yang ditandai dengan beberapa orisinalitas tertentu. Hal ini seperti yang tertuang dalam Pasal 9 ayat 2 TRIPs, "Copyright protection shallextend to expressions and not to ideas, prosedures, methods of operation or mathematical concepts as such".Suatu ciptaan tidak memenuhi syarat untuk memperoleh hak cipta, kecuali apabila ciptaan tersebut telah ditulis, direkam atau diwujudkan dalam bentuk materiil.

Akan tetapi, karena sulitnya menentukan kapan suatu ciptaan telah selesai dibuat, maka UU tentang Hak Cipta memberikan ketentuan bahwa pengakuan dan perlindungan atas suatu ciptaan setelah ciptaan tersebut untuk pertama kalinya dipublikasikan atau diumumkan. Bagi pencipta maupun pemegang hak cipta yang 
mendaftarkan ciptaannya, pendaftaran ciptaan pada Dirjen HKI hanya sebagai alat bukti yang kuat bahwa ia adalah pencipta, apabila terjadi sengketa di pengadilan. Hal ini dikarenakan dalam prinsip dasar, Hak cipta itu lahir setelah karya cipta itu selesai dibuat, pendaftaran bukan merupakan suatu keharusan, pendaftaran ciptaan tidak mengandung arti sebagai pengesahan atas isi, arti atau bentuk dari ciptaan yang didaftarkan. ${ }^{36}$

Karya cipta baik merupakan salah satu objek perlindungan hak cipta. Seni batik secara konvensional dilindungi sebagai bentuk ciptaan tersendiri. Batik sebagai karya yang memiliki nilai seni, baik pada ciptaan motif, gambar, maupun komposisi warnanya. Disamakan dengan batik adalah karya tradisional lainnya yang merupakan kekayaan bangsa Indonesia, seperti seni songket, ikat, dan lainlain $^{37}$. Saat ini pelaku usaha produk batik telah sadar akan arti penting perlindungan kekayaan intelektual sehingga penting untuk melindungi karya cipta produk batik mereka ${ }^{38}$.

Karya cipta batik yang dibuat berdasarkan pesanan dari seseorang atau institusi kepada pelaku usaha produk batik di Kota Semarang dapat diketahui siapa penciptanya dengan melihat perjanjian yang dibuat diantara keduanya. Bila tak ada perjanjian maka dapat dilihat siapa yang memiliki ide dalam pembuatan motif karya batik berdasarkan pesanan tersebut. Dalam beberapa keadaan, hak cipta atas karya batik yang dibuat oleh pihak yang disewa adalah milik pihak yang mempekerjakan, bukan pencipta. Dasar ini diperkuat dengan adanya perjanjian sebelum pekerjaan tersebut dilakukan atau jika tidak ada perjanjian maka dilihat siapa yang membuat atau ide pembuatan karya batik tersebut. Jika motif yang dibuat adalah motif yang sudah pernah ada, jelas si pemesan bukanlah penciptanya, tetapi jika motif itu benar-benar baru maka si pemesanlah pencipta sebenarnya.

\footnotetext{
36 Muhamad Djumhana, R. Djubaedilah. Hak Milik Intelektual, Sejarah, Teori dan Prakteknya di Indonesia, Cetakan Ketiga. (Bandung : Citra Aditya Bakti, 2003), halaman. 55.

${ }^{37}$ Rahmi, Jened, Hukum Hak Cipta (Copyright's Law), (Bandung, PT. Citra Aditya Bakti, 2014), halaman 95.

${ }^{38}$ Rohaida, Noedin \& Siti Safina Abu Bakar. 2017. Malaysian Batik Industry: Protecting Local Batik Design By Copyright And Industrial Design Laws, International Journal of Business and Society, Vol. 13 No. 2, 2012, 117 - 132, halaman 129.
} 
Sebuah karya batik yang dibuat berdasarkan pesanan, maka si pemesanlah pemilik karya cipta tersebut (kecuali jika ada perjanjian diantara keduanya yang menyetujui sebaliknya).

Ciptaan berdasarkan hubungan kerja atau pesanan telah diatur dalam Undang-Undang Hak Cipta Nomor 28 Tahun 2014 pada Pasal 36, dijelaskan bahwa "Jika suatu Ciptaan dibuat dalam hubungan kerja atau berdasarkan pesanan, pihak yang membuat karya cipta itu dianggap sebagai pencipta dan pemegang hak cipta, kecuali apabila diperjanjikan lain antara kedua pihak", yang dimaksud dengan hubungan kerja atau berdasarkan pesanan ini adalah ciptaan yang dibuat atas dasar hubungan kerja lembaga swasta atau dasar pesanan pihak lain.

Apabila timbul sengketa diantara kedua belah pihak maka menurut Pasal 97 ayat 1 dan 2, diterangkan bahwa apabila dalam hal ciptaan telah dicatat maka pihak lain yang berkepentingan dapat mengajukan gugatan pembatalan pencatatan ciptaan, gugatan yang dimaksud ditujukan kepada Pencipta/Pemegang Hak Cipta terdaftar.

Kenyataan yang terjadi di masyarakat Indonesia, masih banyak pelanggaran hak cipta, meskipun Indonesia telah memiliki UU Hak Cipta. Perkembangan yang ada di dalam masyarakat telah terjadi perdebatan antara kebutuhan masyarakat secara ekonomi dan sikap penghargaan hak cipta ${ }^{39}$.

\section{Pencipta/Pemegang Hak Cipta dalam Suatu Hubungan Kerja}

Berdasarkan Pasal 36 Undang-Undang Nomor 28 Tahun 2014 tentang Hak Cipta dijelaskan bahwa "Jika suatu Ciptaan dibuat dalam hubungan kerja atau berdasarkan pesanan, pihak yang membuat karya cipta itu dianggap sebagai pencipta dan pemegang hak cipta, kecuali apabila diperjanjikan lain antara kedua pihak", yang dimaksud dengan hubungan kerja atau berdasarkan pesanan ini adalah ciptaan yang dibuat atas dasar hubungan kerja lembaga swasta atau dasar pesanan pihak lain. Seangkan menurut Pasal 34 Undang-Undang Nomor 28 Tahun 2014 tentang Hak Cipta dijelaskan bahwa "dalam hal ciptaan dirancang

\footnotetext{
${ }^{39}$ Suyud Margono, Hukum Hak Cipta Indonesia, (Bogor: Ghalia Indonesia, 2010), halaman 144 
oleh seseorang dan diwujudkan serta dikerjakan oleh orang lain dibawah pimpinan dan pengawasan orang yang merancang, yang dianggap Pencipta yaitu Orang yang merancang Ciptaan”.

Yang menjadi aspek terpenting dalam permasalahan ini adalah perjanjian antara perusahaan dan pekerja. Bagaimana isi perjanjian antara kedua belah pihak tersebut. Apa saja aspek-aspek yang dituangkan dalam perjanjian tersebut, apakah terjadi pengalihan hak atau hanya lisensi. Klausul serta isi dalam perjanjian tersebut akan sangat menentukan siapa pihak yang berkedudukan sebagai Pemegang Hak Cipta yang memiliki hak untuk mengomersialisasikan Ciptaan.

Penting bagi kepemilikan kekayaan intelektual oleh seorang pelaku usaha adalah perjanjian tertulis dengan karyawan tersebut, yang secara khusus memberikan kepada si pelaku usaha setiap dan semua kekayaan intelektual yang diciptakan oleh karyawan selama masa kerjanya. Dengan tidak adanya kesepakatan seperti itu, karyawan dapat memiliki hak kepemilikan dalam kekayaan intelektual yang ia ciptakan saat bekerja untuk perusahaan, bahkan jika individu tersebut secara khusus dipekerjakan untuk menciptakan suatu produk atau proses tertentu.

Pelaku usaha batik yang memiliki beberapa pekerja tidak pernah membuat perjanjian khusus terutama berkaitan dengan motif yang mereka ciptakan. Umumnya pekerja yang mereka pekerjakan bersifat sederhana. Membayar per bulan atau membayar per datang. Ketentuan mengenai siapa pencipta dari motif yang diciptakan tidak menjadi persoalan karena sampai sekarang tidak ada gugatan terhadap hal demikian. Namun bukan berartitidak akan terjadi persoalan konflik kepemilikan hak cipta terhadap motif yang diciptakan bersama dengan si perkeja atau dibuat sendiri oleh si pekerja.

Untuk menghindari perselisihan mengenai siapa pencipta dari ciptaan yang timbul karena hubungan kerja, perlu adanya perjanjian yang jelas antara si pelaku usaha dengan si pekerrja. Perjanjian tersebut dilaksanakan sebelum dimulainya hubungan kerja, di mana pelaku usaha mengidentifikasi semua kekayaan intelektual di mana dia memiliki kepentingan kepemilikan sebelum dimulainya pekerjaannya. Pelaku usaha juga harus memastikan perjanjian tertulis sesuai 
dengan ketentuan hukum yang berlaku. Selanjutnya, pelaku usaha harus memasukkan hal yang merinci apa yang terjadi jika karyawan menyalahgunakan dan / atau melanggar kepemilikan intelektual si pelaku usaha.

Jika tidak ada perjanjian kerja, kebijakan, atau perjanjian tertulis untuk mengalihkan hak kepada pemberi kerja, pemberi kerja mungkin bisa menyatakan hak kepemilikan atas ciptaan karyawan yang dibuat selama masa kerja karyawan. Keterlambatan dalam analisis kepemilikan seringkali adalah apakah gagasan itu diciptakan "dalam proses kerja." Tidak cukup bagi seorang pelaku usaha untuk menunjuk bukti pembayaran gaji/upah dan mengklaim semua ide karyawan. Sebaliknya, ide yang dipermasalahkan harus diciptakan selama hubungan kerja. Dengan demikian, karyawan memiliki ide karena mereka dikembangkan di luar hubungan kerja, maka jelas karyawan itu lah si penciptanya.

Fokus utama dari analisis ini akan menjadi alasan untuk mempekerjakan karyawan tertentu. Jika karyawan dipekerjakan untuk menciptakan kekayaan intelektual sebagai bagian dari pekerjaan mereka, pelaku usaha (pengusaha) akan menjadi pemilik kekayaan intelektual. Dengan demikian, kontrak kerja tertulis dan tugas-tugas yang diuraikan di sini dapat menjadi bukti dari penyelidikan kepemilikan. Tanpa persetujuan tertulis, pengadilan akan melihat sifat dari posisi dan apakah pemberi kerja memberi arahan atau menetapkan tujuan bagi karyawan untuk dicapai ciptaan tersebut. Ide-ide yang berasal dari arahan ini umumnya akan menjadi milik si pengusaha/pelaku usaha.

\section{PENUTUP}

Ciptaan berdasarkan pesanan atau hubungan kerja telah diatur sedemikian rupa pada Undang-Undang Nomor 28 Tahun 2014 tentang Hak Cipta. Dilihat pada Pasal 36 Undang-Undang Hak Cipta menjelaskan bahwa jika suatu Ciptaan dibuat dalam hubungan kerja atau berdasarkan pesanan, pihak yang membuat karya cipta itu dianggap sebagai pencipta dan pemegang hak cipta, kecuali apabila diperjanjikan lain antara kedua pihak, tetapi pada Pasal 34 Undang-Undang Hak Cipta menjelaskan bahwa dalam hal ciptaan dirancang oleh seseorang dan diwujudkan serta dikerjakan oleh orang lain dibawah pimpinan dan pengawasan 
orang yang merancang, yang dianggap Pencipta yaitu Orang yang merancang Ciptaan. Dapat disimpulkan bahwa apabila suatu ciptaan dalam hubungan kerja dimana perusahaan merupakan pihak yang merancang dan dikerjakan oleh pihak lain yakni karyawan maka pencipta nya adalah perusahaan tersebut namun apabila perusahaan meminta karyawan nya untuk merancang serta membuat suatu ciptaan maka pencipta serta pemegang hak cipta tersebut adalah yang membuat ciptaan tersebut yang dalam hal ini adalah karyawan, tetapi jika ciptaan tersebut telah diperjanjikan lain oleh kedua belah pihak maka perjanjian tersebut bisa menentukan siapa pihak yang berkedudukan sebagai Pemegang Hak Cipta. 


\section{DAFTAR PUSTAKA}

Bogdan, Robert dan Steven J. Taylor. 1992. Pengantar Metode Penelitian Kualitatif.Terjemahan Ali Furchan, Surabaya : Usaha Nasional

Coffey, Amanda. 2004. Reconceptualizing Social Policy: Sosiological Perspective on Contemporary Social policy, Berkshire-England: Open University Press, McGraw Hill Educations

Djumhana, Muhammad \& R. Djubaedilah. 2003. Hak Milik Intelektual, Sejarah, Teori dan Prakteknya di Indonesia, Cetakan Ketiga. Bandung : Citra Aditya Bakti

Faisal, Sanfiah. 1990. Penelitian Kualitatif : Dasar-Dasar dan Aplikasinya, Malang : Yayasan Asah Asih Asuh

Janed, Rahmi. 2014. Hukum Hak Cipta (Copyright's Law), Bandung: PT. Citra Aditya Bakti

Kennedy, Kristen B. 2017. Copyright Infringement in Sound Recording: How Courts and Legislatures Can Get in Vogue in a Post-Ciccone World. Vol.25, Number 12. Hlm.20

Miles, Matthew B dan A. Michael Huberman. 1992. Analisis Data Kualitatif. Terjemahan Tjetjep Rohendy Rohidi. Jakarta : UI Press.

Margono, Suyud. 2010. Hukum Hak Cipta Indonesia, (Bogor: Ghalia Indonesia

Nasution. 1992. Metode Penelitian Naturalistik. Bandung : Tarsito

Noedin, Rohaida \& Siti Safina Abu Bakar. 2017. Malaysian Batik Industry: Protecting Local Batik Design By Copyright And Industrial Design Laws, International Journal of Business and Society, Vol. 13 No. 2, 2012, 117 - 132

Strauss, A and J. Corbin. 1990. Qualitative Research, Grounded Theory Procedure and Techniques, London : Sage Publication

Sutopo, H.B. 1990, Metodologi Penelitian Kualitatif Bagian II, Surakarta: Universitas Sebelas Maret Press

Sudarto. 2002. Metode Penelitian Filsafat, Jakarta : Raja Grafindo

Steelyana, Evi. 2012. Batik, A Beautiful Cultural Heritage That Preserve Culture And Support Economic Development In Indonesia, Binus Business Review, Vol. 3, No. 1, 116-130 